\title{
Assessment of shrinkage characteristic in blended cement and fly ash admixed soft clay
}

\author{
T. Chompoorat ${ }^{\text {i) }}$ and S. Likitlersuang ${ }^{\text {ii) }}$
}

i) Assistant Professor, Department of Civil Engineering, School of Engineering, University of Phayao, Thailand. ii) Professor, Department of Civil Engineering, Faculty of Engineering, Chulalongkorn University, Thailand.

\begin{abstract}
This paper aims to present a study of a shrinkage potential of cement and/or fly ash treated soft clay. The soft clay specimens used in this study were prepared from reconstituted Bangkok clay. The soil-cement mix specimens were prepared with cement/clay-water ratio $\left(\mathrm{C} / w_{\mathrm{c}}\right)$ of $0.2,0.3$ and 0.4 and the liquidity index (LI) of 1.0, 1.3 and 1.6. The fly ashes as wastes from the electricity generating industries were used in this study. The replacement ratios of fly ash to cement were varied from 15 to $60 \%$ by weight. The experiments were performed to determine the strength, stiffness and shrinkage potential. The strength and stiffness were determined by the unconfined compressive strength (UCS) and the secant Young's modulus at $50 \%$ of strength $\left(E^{50}\right)$. The shrinkage potential was loosely defined based on an image processing technique. Finally, the results of the study could be used to draw a conclusion of optimised fly ash and cement contents for the soft soil improvement.
\end{abstract}

Keywords: soil stabilisation, cement, fly ash, strength, shrinkage

\section{INTRODUCTION}

It is well-known that chemical stabilisation is an effective method used to improve the problematic soils such as soft clay and expansive soil. The change of the soil properties which may be relevant to the cementation of the particles is usually resulted from utilising of chemical additives. From the top list of additives for soil stabilisation, cement is previously the most general mixing agent. There are the notable mechanical researches presented by Terashi et al. (1980), Kamon and Bergado (1992), and Horpibulsuk et al. (2004, 2010, and 2011) which are studied through laboratory and numerical model of cement admixed clays. The quantity of cement is added according to the plasticity property of soil. The higher the plasticity index of soil, the bigger quantity of cement requires in stabilising the soil. The problem related to cement mixtures, which is mostly encountered in fine-grained soils, is the incidence of shrinkage cracks. But recent studies have shown that many of the soil problems can be ameliorated by the addition of pozzolanic fly ash (Lee, 1996; Nilo et al., 2001; Osinubi et al., 2006; Cho et al., 2006). The addition of fly ash influences on ion exchanging occurred in the soil particle surface. This leads to the flocculation and the agglomeration of the clay particles which is very much the same as the effect of cement. From above rearrangement of soil particles the performance of soil structure is improved, resulting in lowering the rate of swell, shrinkage and plasticity (Natt and Joshi, 1984; Bowders et al., 1987; Nicholson and Kasyap, 1993). It was found by Lee (1996) that dry shrinkage is reduced to approximately $10 \%$ when the replacement of fly ash is enlarged to $10 \%$. In accordance with these studies the fly ash performs as the shrinkage-reducing agent decreasing the surface tension of permeating water.

One of the most applications of cement stabilisation is enhancing stability of road embankment on soft soil. Shrinkage of soil cement happened in subgrade, subbase, and/or base of road embankment will be occurred after mixing soil and cement. Hydration reaction causing harder of soil cement mix is raised from the blended water. The water will be evaporated out through the pavement surface. The water will afterward gradually evaporate out according to the conditions of air temperature and relative humidity. The transverse crack will be produced by this shrinkage in soil cement and it will be taken place by starting from road shoulder. The longitudinal crack will also be occurring afterward. Mostly the crack resulting from the shrinkage still cannot be kept away from the construction. The shrinkage happening in soil cement mix is one of the serious factors leading to the road damage. This is because when the cracking influenced by the shrinkage takes place, it could induce the water flowing through and causing the instability of embankment. In consequence of this way the shrinkage potential of cement with and without fly ash treated soft clay is studied. Two fly ashes selected for this study are the wastes from electricity generating process. The first 
one known as the high-quality fly ash in Thailand is from the Mae Moh Power Plant of Electricity Generating Authority of Thailand (EGAT). Another one is from a private paper industry in Thailand.

\section{SHRINKAGE}

The cement shrinkage can be categorised into three types which are autogenous shrinkage, dry shrinkage, and carbonation shrinkage. Autogenous shrinkage and dry shrinkage are resulted from the water composition inside the cement. For carbonation shrinkage, Naville (1995) and Kim (2003) presented that it is influenced by the water evaporation which is raised from the chemical reaction between $\mathrm{Ca}(\mathrm{OH})_{2}$ in the cement and $\mathrm{CO}_{2}$ in the air. Considering the category of those shrinkages, the major shrinkage is caused by the moisture fluctuation prematurely. At the stage of hydration autogenous shrinkage will take place when the motion of water does not occur from the cement. Dry shrinkage will be taken place when the water inside the void of cement is evaporated resulting from contacting with the ambient environment. There are three assumptions proposed by George (1968) to illuminate the understanding in dry shrinkage happened in soil cement. It is explained that the capillary tension have more impact from high humidity than at the medium humidity. Next, the contraction is caused by the reduction of the adsorbed water firm. Then, the shrinkage occurred by losing water from the crystal lattice of the soil when the humidity is continued to decrease.

In order to reduce early-age dry shrinkage, there are two ways in general. The former is to control the mix design regarding the adjustment of the quantity of mixtures which are water, cement, and aggregate. The latter is to add the fly ash (Sherman, 1974) which this research focuses on. Shrinkage reducing agents are regarded as nonionic surface active agents containing the components which can lessen the surface tension of water in capillary pores. The water in the void will not be able to evaporate when the capillary voids are very small. The excessive water between the layers will be evaporated when the voids enlarged to a certain size. The surface tension had become harder after the evaporation of excessive water. The tension happened in the cement gel led to the shrinkage. By using only $1.5 \%$ to $2.0 \%$ of a shrinkage-reducing agent, the surface tension of capillary water inside the hardening cement can be reduced for $40 \%$ to $50 \%$ and the autogenous shrinking strain is also decreased for approximately 30\%. (Lee, 1996)

\section{MATERIALS AND METHODS}

\subsection{Materials}

The materials used in this research are (1) reconstituted Bangkok clay (BKK clay) (2) type I Portland cement and (3) Fly ash \#1 acquired from the lignite-fired power generation of Mae Moh Power Plant in Lampang province and Fly ash \#2 obtained from the electricity generating process of a private paper industry in Ratchaburi province. The values of their chemical composition are presented in Table 1. Their specimen physical characteristic in terms of shape and size of soft BKK Clay, Portland cement, and fly ash from two sources are additionally displayed in Fig. 1.

Table 1 Chemical composition of materials from X-ray fluorescence (XRF) test.

\begin{tabular}{ccccc}
\hline $\begin{array}{c}\text { Chemical } \\
\text { Composition (\%) }\end{array}$ & $\begin{array}{c}\text { BKK } \\
\text { clay }\end{array}$ & $\begin{array}{c}\text { Portland } \\
\text { cement }\end{array}$ & $\begin{array}{c}\text { Fly ash } \\
\# 1\end{array}$ & $\begin{array}{c}\text { Fly ash } \\
\# 2\end{array}$ \\
\hline $\mathrm{SiO}_{2}$ & 62.70 & 20.90 & 30.90 & 24.10 \\
\hline $\mathrm{Al}_{2} \mathrm{O}_{3}$ & 21.00 & 4.76 & 17.60 & 10.30 \\
\hline $\mathrm{Fe}_{2} \mathrm{O}_{3}$ & 7.50 & 3.41 & 14.80 & 3.58 \\
\hline $\mathrm{CaO}$ & 0.87 & 65.41 & 23.24 & 49.80 \\
\hline $\mathrm{MgO}$ & 1.86 & 1.25 & 2.12 & 2.44 \\
\hline $\mathrm{SO}_{3}$ & 0.88 & 2.71 & 3.87 & 1.45 \\
\hline $\mathrm{Na}_{2} \mathrm{O}$ & 0.96 & 0.24 & 1.50 & 0.33 \\
\hline $\mathrm{K}_{2} \mathrm{O}$ & 2.79 & 0.35 & 2.73 & 0.60 \\
\hline $\mathrm{LO}$ & - & 0.96 & 1.20 & 1.44 \\
\hline
\end{tabular}

In reference to the chemical composition data from XRF test, it is found that Fly ash \#1 is in quality level of class C and Fly ash \#2 is lower than quality level of class $\mathrm{C}$ according to standard ASTM C618. Referring to Fig. 1, it is shown that the particle size of each specimen of BKK clay, Portland cement, Fly ash \#1, and Fly ash \#2 is different in the span of 1 to $40 \mu \mathrm{m}$. Their particle surface and particle shape are also obviously different from each other. The particles of BKK clay look flaky. Portland cement has individually angular particles. Most of Fly ash \#1's particles are small rounded shape. The particles of Fly ash \#2 are stick together with quite random shape.
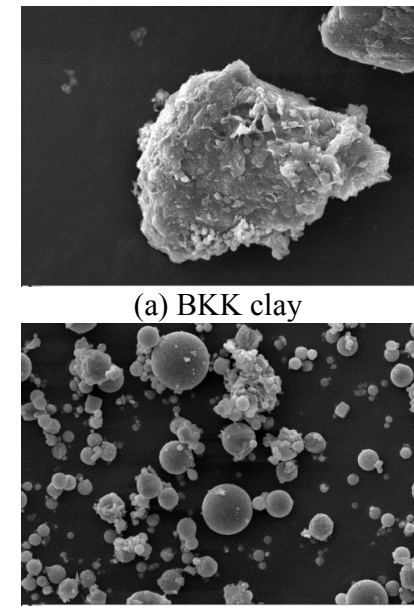

(c) Fly ash \#1

Fig. 1. SEM photos.

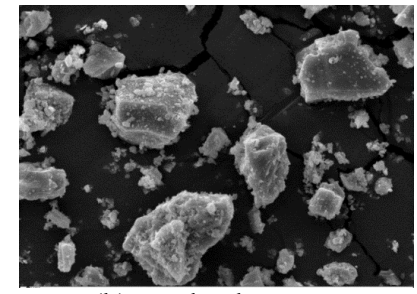

(b) Portland cement

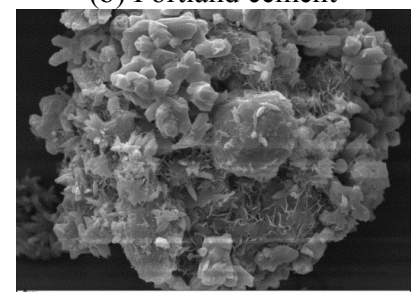

(d) Fly ash \#2

\subsection{Sample preparation and testing programme}

The reconstituted sample was prepared in order to debond the natural bonding of BKK soft clay. The clay specimen was ground and dried into powder. The BKK clay powder was mixed with water, cement, fly ash 
according to the condition in Table 2. The specimens of unconfined compression (UC) test were prepared using the PVC cylindrical mould of $57 \mathrm{~mm}$ diameter and 114 $\mathrm{mm}$ height. For drying shrinkage test, the specimens were put in the acrylic mould with the dimension of 25 $\mathrm{mm} \times 25 \mathrm{~mm} \times 285 \mathrm{~mm}$. The white colour makes the observation easy to distinguish by image processing.

Table 2 Summary of experimental programme

\begin{tabular}{lcccc}
\hline \multicolumn{1}{c}{ Test } & $\mathbf{C} / \boldsymbol{w}_{\mathbf{c}}$ & $\begin{array}{c}\mathbf{L I} \\
\left(\mathbf{\%} \boldsymbol{w}_{\mathbf{c}}\right)\end{array}$ & Fly ash & $\begin{array}{c}\text { Curing } \\
(\text { day })\end{array}$ \\
\hline UC test & $\begin{array}{c}0.2,0.3, \\
0.4\end{array}$ & $\begin{array}{c}1.0,1.3, \\
1.6\end{array}$ & - & 7,28 \\
\cline { 2 - 5 } & $0.3,0.4$ & 1.6 & $\begin{array}{c}0,15,30, \\
45,60\end{array}$ & $7,28,60$ \\
\hline $\begin{array}{l}\text { Drying } \\
\text { shrinkage test }\end{array}$ & $0.3,0.4$ & 1.6 & $\begin{array}{c}0,15,30, \\
45,60\end{array}$ & $\begin{array}{c}1,3,5,7, \\
14,21,28\end{array}$ \\
\hline
\end{tabular}

The UC tests were carried out to examine the unconfined compressive strength (UCS) of BKK clay blended with cement and/ or fly ash in accordance with ASTM D2166. The clay powder, cement and/or fly ash were blended with the water and placed in the mould. After mixing, the mix was kept in the mould for two hours for setting. The final specimen was warped with plastic sheet and cured in the dry place at $25^{\circ} \mathrm{C}$. During test, the specimen was compressed with the loading rate of $0.5 \% / \mathrm{min}$ to the vertical strain of $2 \%$.

The test of drying shrinkage was run under the standard of ASTM C596. After sample preparation, the specimen was cured in the oven at $25^{\circ} \mathrm{C}$ and $80 \%$ of relative humidity to generate the completed hydration reaction within 7 days. The drying shrinkage test was carried out afterwards by placing the specimens under the room condition as presented in Fig. 3. The specimen was shot by digital camera at the same position at each curing time as in Table 2. The picture of the zero-day curing was firstly investigated to find out the beginning pixel number which is considered as the pixel size prior to the shrinkage. The pixel numbers of pictures at other curing times were also then measured. The pixel number of cracking and shrinkage area from the pictures were digitally counted. The percentage of the shrinkage is defined as the ratio between the number of shrinkage pixel and the beginning pixel number as displayed in Fig. 3

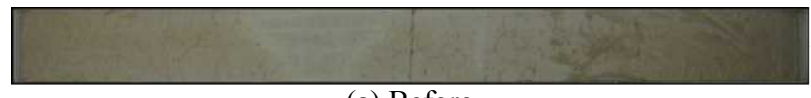

(a) Before

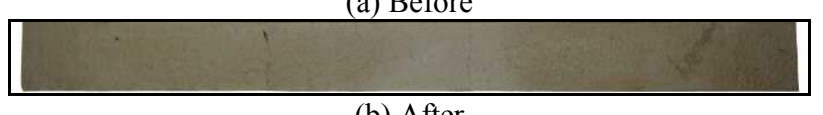

(b) After

Fig. 3 Drying shrinkage test

\section{RESULT AND DISCUSSION}

\subsection{Unconfined compression test}

The results of UC tests indicate that the value of UCS and $E^{50}$ highly increase in the first 28 days. This is because the hydration reaction resulted in the soil cement hardening. The UCS and $E^{50}$ are also raised according to the increase of $\mathrm{C} / w_{\mathrm{c}}$. In addition to the UC test, it is found that at the same $\mathrm{C} / w_{\mathrm{c}}$, no matter where the water levels are, the value of both UCS and $E^{50}$ will be slightly decreased in accordance with the raising of water. This also conforms to the research of Horpibulsuk et al. (2011). As the result of the test, it reveals that at the same $\mathrm{C} / w_{\mathrm{c}}$ within the range from 0.2-0.4 and in the condition of water level at LI $=1.0$ to $\mathrm{LI}=1.6$, the UCS and $E^{50}$ will approximately be equivalent as illustrated in Fig. 4.

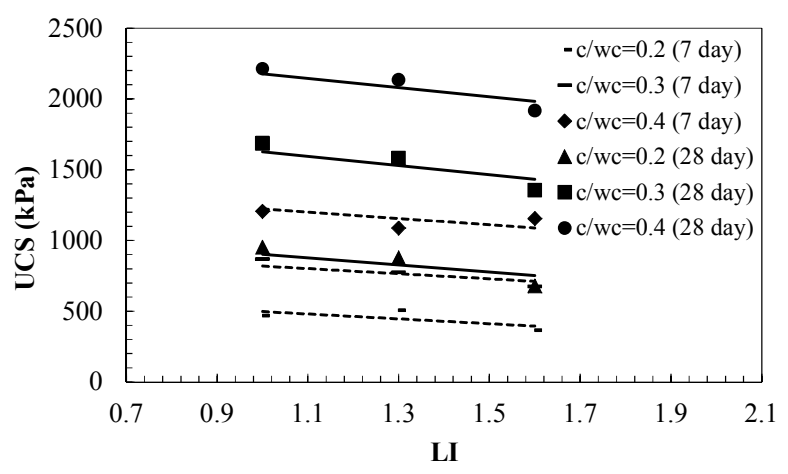

(a)

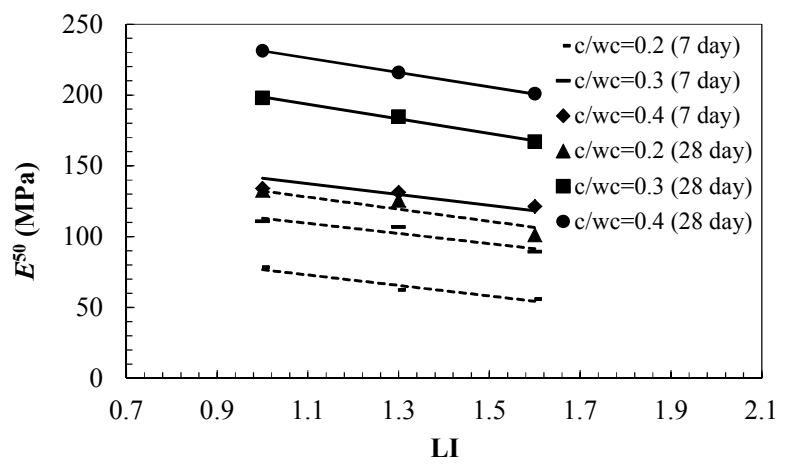

(b)

Fig. 4 (a) Relation between UCS and LI of soil cement (b) Relation between $E^{50}$ and LI of soil cement

The specimens mixed with fly ash under the same conditions also show the same response according to the longer curing time during first 28 days. However, after 28 days, UCS and $E^{50}$ were gradually increased until 60 days resulting from long-term pozzolanic reaction. Both relationships of UCS and $E^{50}$ with time are presented in Fig. 5 and 6, respectively. The values of UCS and $E^{50}$ of soil cement replaced by fly ash, which were tested under conditions in Table 2 were gradually decreased when the substitution of fly ash were increased. This relation is happened in both the replacement by Fly ash\#1 and Fly ash \#2. When comparing the mix of Fly ash \#1 and Fly ash \#2, the values of UCS and $E^{50}$ of Fly ash \#2 are slightly higher than Fly ash \#1 because the physical characteristic of Fly ash \#2 particle is angular which less active than the round particle of Fly ash \#1. 


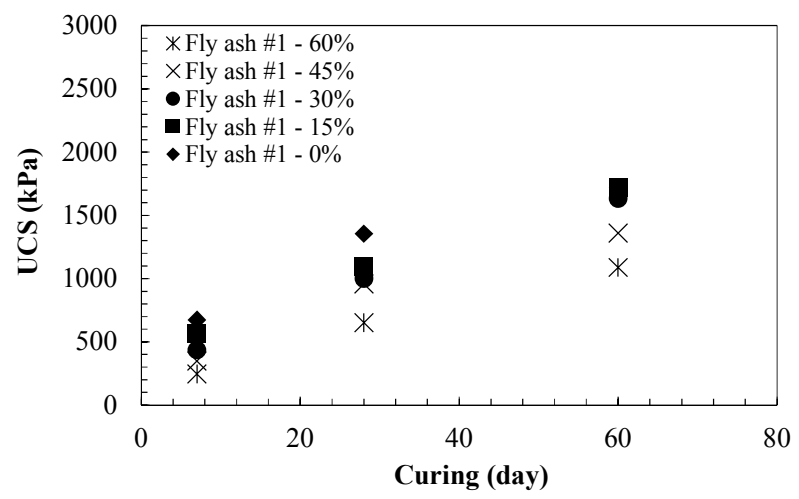

(a) $\mathrm{C} / w_{\mathrm{c}}=0.3$ and Fly ash $\# 1$

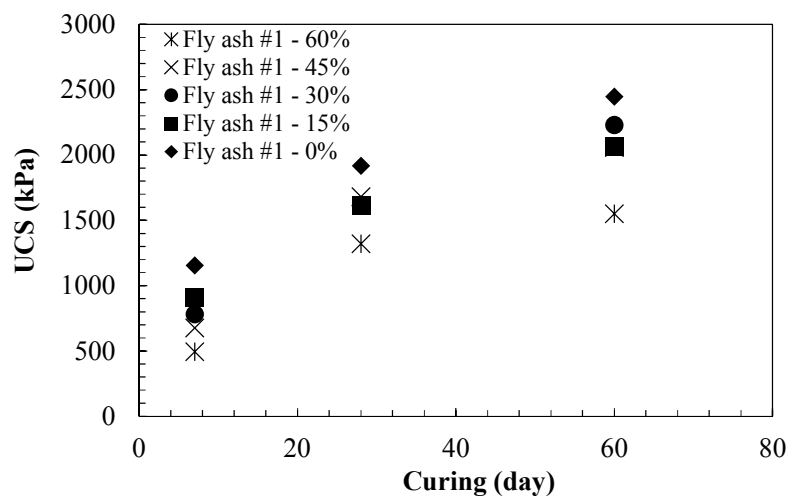

(b) $\mathrm{C} / w_{\mathrm{c}}=0.4$ and Fly ash \#1

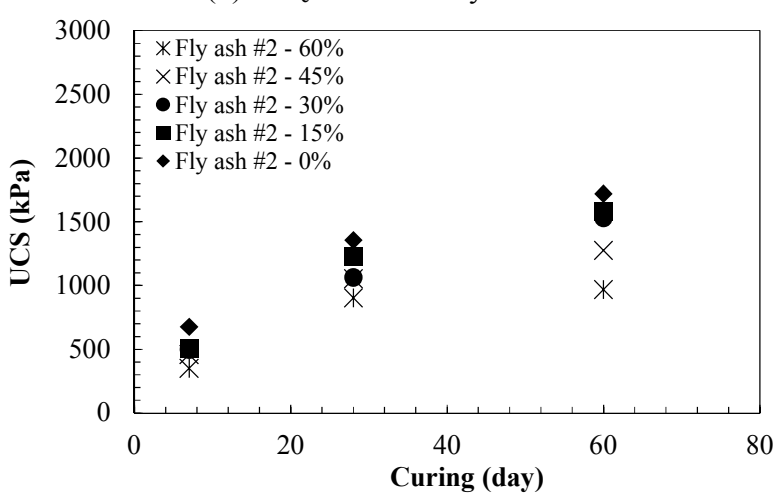

(c) $\mathrm{C} / w_{\mathrm{c}}=0.3$ and Fly ash \#2

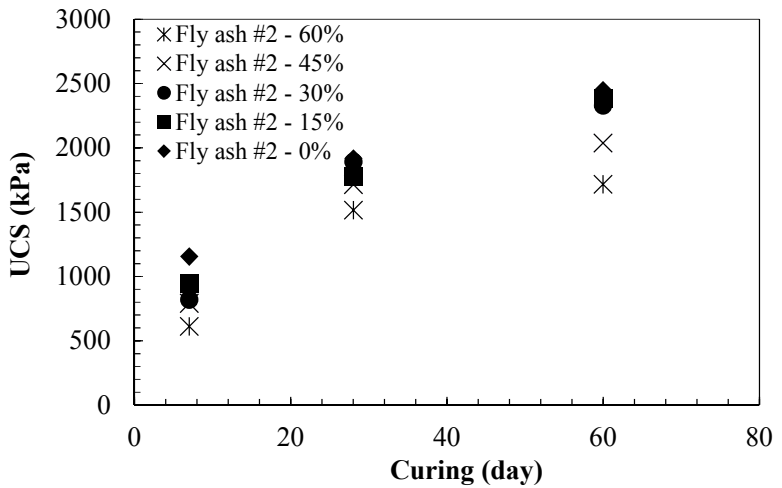

(d) $\mathrm{C} / w_{\mathrm{c}}=0.4$ and Fly ash $\# 2$

Fig. 5 Relation between UCS and curing time

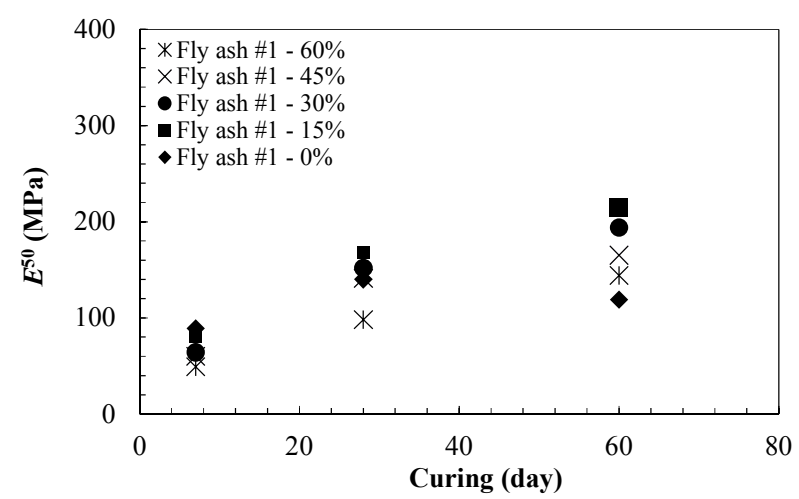

(a) $\mathrm{C} / w_{\mathrm{c}}=0.3$ and Fly ash \#1

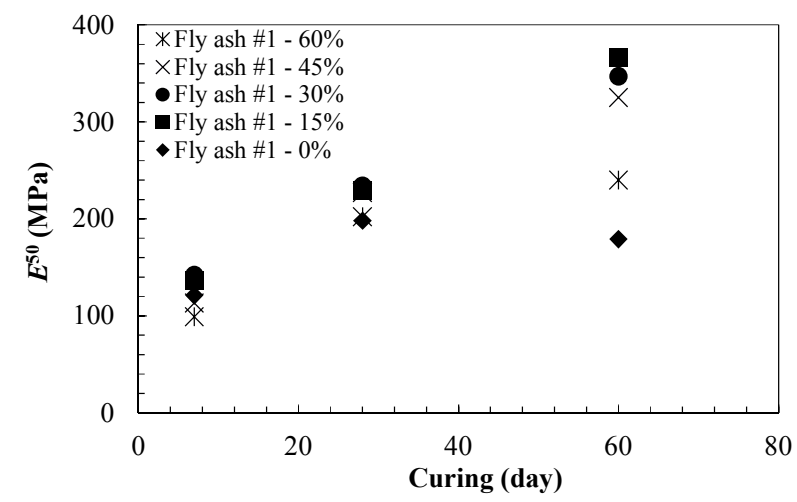

(b) $\mathrm{C} / w_{\mathrm{c}}=0.4$ and Fly ash \#1

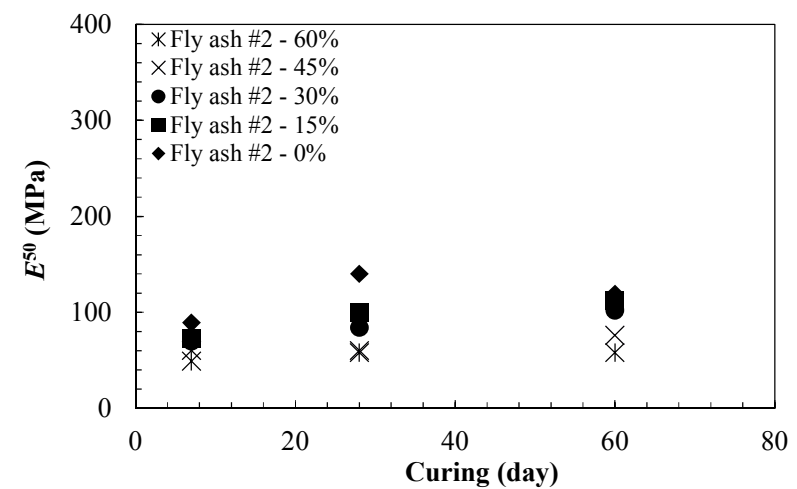

(c) $\mathrm{C} / w_{\mathrm{c}}=0.3$ and Fly ash $\# 2$

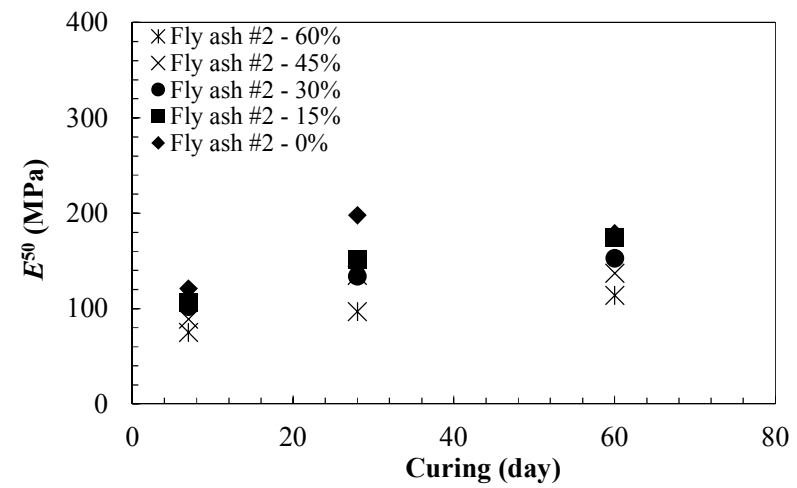

(d) $\mathrm{C} / w_{\mathrm{c}}=0.4$ and Fly ash $\# 2$

Fig. 6 Relation between $E^{50}$ and curing time 


\subsection{Drying shrinkage test with image processing}

The drying shrinkage test of soil cement specimens referring to testing conditions in Table 2 found that the shrinkage value of samples is around 4-8\% at first 7 days. This is from the hydration reaction and evaporation happened on the specimen surface. The shrinkage after 7 days until 28 days was very small approximately less than $1 \%$. This may be because the free water already escaped from the specimens and the rate of hydration reaction was lowered. This causes in extremely lowering the rate of shrinkage. Fig. 7 shows the shrinkage of soil cement mixed with Fly ash \#1 and Fly ash \#2 with respect to curing time.

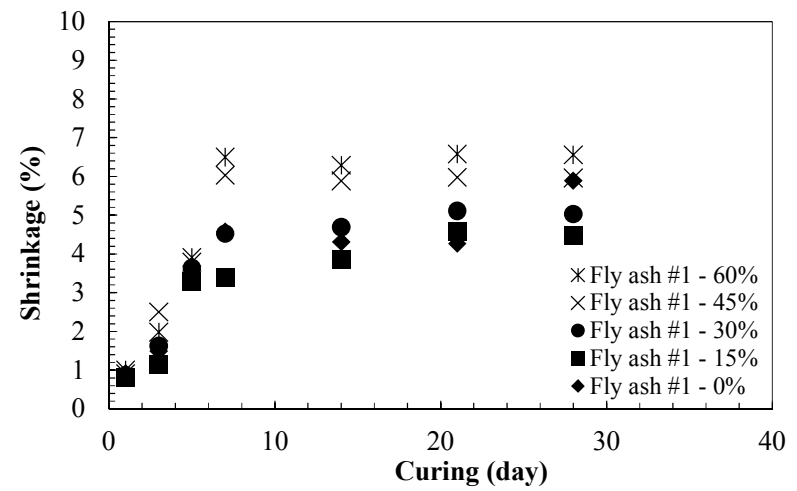

(a) $\mathrm{C} / w_{\mathrm{c}}=0.3$ and Fly ash $\# 1$

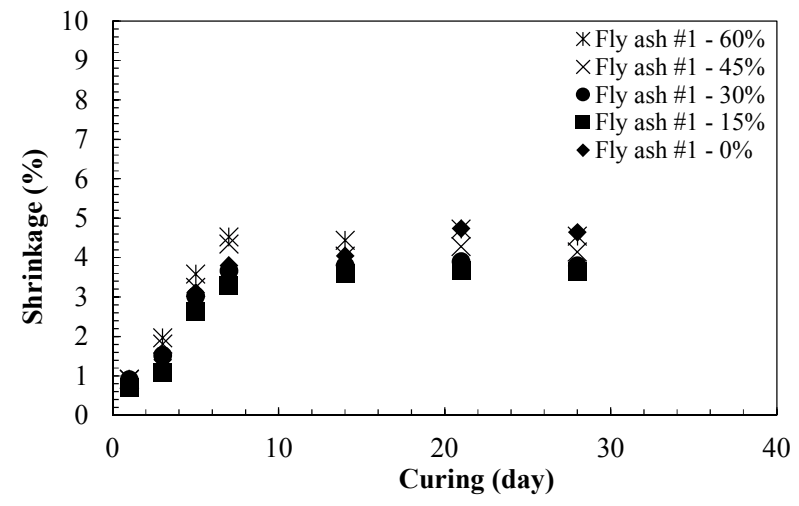

(b) $\mathrm{C} / w_{\mathrm{c}}=0.4$ and Fly ash \#1

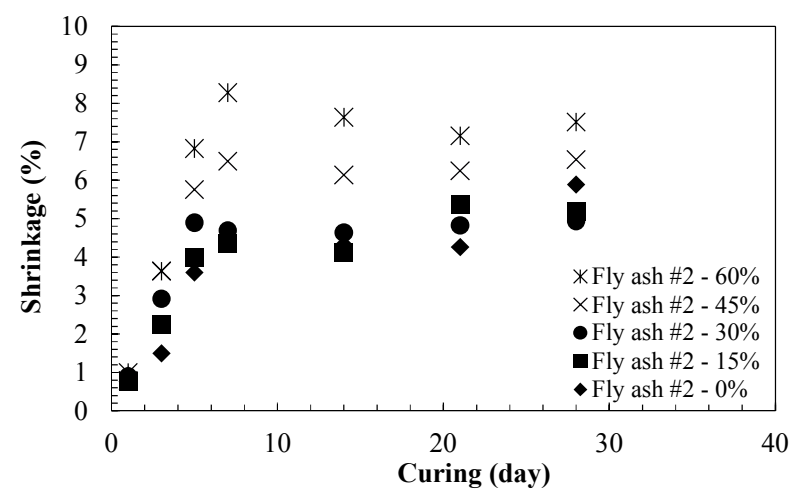

(c) $\mathrm{C} / w_{\mathrm{c}}=0.3$ and Fly ash $\# 2$

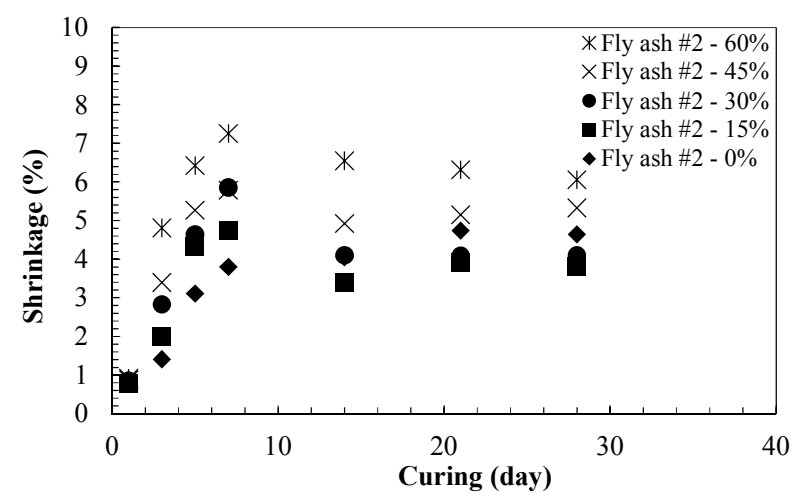

(d) $\mathrm{C} / w_{\mathrm{c}}=0.4$ and Fly ash \#2

Fig. 7 Relation between dry shrinkage and curing time

Additionally, the shrinkage at 28 days of the soil cement mixed with $15 \%$ fly ash for both Fly ash \#1 and Fly ash \#2 are displayed in Fig.8. This amount of 15\% replacement of fly ash was an optimum value that provides the lowest shrinkage value.

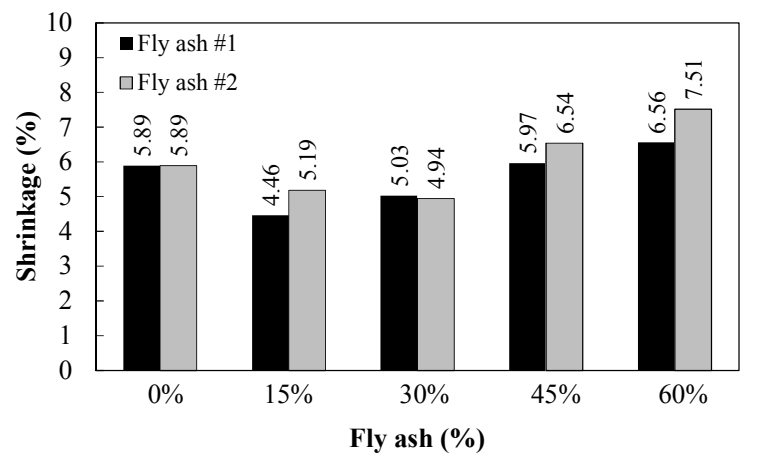

(a) $\mathrm{C} / w_{\mathrm{c}}=0.3$

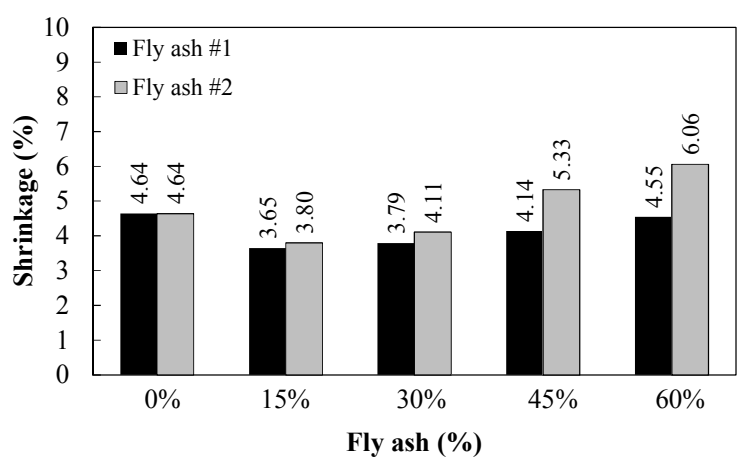

(b) $\mathrm{C} / w_{\mathrm{c}}=0.4$

Fig. 8 Effect of fly ash on shrinkage at 28-day curing

From the comparison between the specimens mixed without and with fly ash, the shrinkage values of samples mixed with $15 \%$ of fly ash are approximately $1 \%$ lower than the shrinkage of the specimen prepared without fly ash. This might be from the rearrangement of the soil particles occurred after replacing the cement by fly ash. The small particles of fly ash can reduce the size of void and this can also decrease the shrinkage rate by the smaller size of the void. This study shows that by replacing the cement by $15 \%$ of fly ash can be 
most lessened the shrinkage; however, the substitution of the fly ash which is higher than $15 \%$ does not help lowering the shrinkage value as exhibited in Fig.8.

Focusing on the soil cement compounded with $15 \%$ of fly ash from each source, the shrinkage percentage of the specimen mixed with Fly ash \#1 is lower than the percentage of those mixed with Fly ash \#2. It moreover reveals that the higher amount of cement mixed in the specimen from $\mathrm{C} / w_{\mathrm{c}} 0.3$ to 0.4 lessens the value of shrinkage. Since the sample becomes stiffer and its strength is higher, the tensile stress inside the void is also higher. This makes the value of shrinkage lower after adding more cement. The shrinkage value above is however not more than the rate from the sample mixed with $15 \%$ of fly ash.

\section{CONCLUSION}

Apart from strength properties of soil cement, shrinkage is also another important property causing the damage of soil cement. Minimising the shrinkage using the low-cost material yet effective will definitely promote to economising the production cost. This research discovers that by applying the fly ash as the waste material, the shrinkage of soil cement can be controlled. The optimised ratio of substituting cement by fly ash found in this study is $15 \%$. Due to the result that this proportion could reduces the void size allowing the water to get into, the hydration and evaporation leading to the shrinkage is also lowered. Beyond this advantage, the experiments also confirm that the $15 \%$ of fly ash replacement does not affect the strength properties.

\section{ACKNOWLEDGEMENTS}

The research was supported by the funds from the annual government statement of expenditure fund University of Phayao. The authors would like to thank Mr. Nopphanan Phannakham for their kind assistance on laboratory works.

\section{REFERENCES}

1) ASTM International (2000): Standard test method for unconfined compressive strength of cohesive soil, ASTM D2166, Washington, D.C.

2) ASTM International (2009): Standard test method for drying shrinkage of mortar containing hydraulic cement, ASTM C596, Washington, D.C.

3) ASTM International (2012): Standard specification for coal fly ash and raw or calcined natural pozzolan for use in concrete, ASTM C618, Washington, D.C.

4) Bowders, J.J., Usmen, M.A. and Gidley, J.S. (1987): Stabilized fly ash for use as low - permeability barrier,
Geotechnical Practice for Waste Disposal, Woods, R. D. ed., Geotechnical Special Publication (GSP), ASCE, 13, 320-333.

5) Cho, Y.H., Lee, K.W. and Ryu, S.W. (2006): Development of cement - treated base material for reducing shrinkage cracks, Journal of the Transportation Research Board, 1952, Washington D.C., 134-143.

6) George (1968): Shrinkage characteristics of soil - cement Highway Research Record 255, Transportation Research Board, Washington D.C., pp. 42-57.

7) Horpibulsuk, S., Bergado, D.T. and Lorenzo, G.A. (2004a): Compressibility of cement admixed clays at high water content, Geotechnique, 54(2), 151-154.

8) Horpibulsuk, S., Miura, N. and Bergado, D.T. (2004b): Undrained shear behavior of cement admixed clays at high water content, Journal of Geotechnical and Geoenvironmental Engineering, ASCE, 130(10), 1096-1105.

9) Horpibulsuk, S., Rachan, R., Chinkulkijniwat, A., Raksachon, Y. and Suddeepong, A. (2011a): Analysis of strength development in cement-stabilized silty clay from microstructural considerations, Construction and Building Materials, 24, 2011-2021.

10) Horpibulsuk, S., Rachan, R. and Suddeepong, A. (2011b): Assessment of strength development in blended cement admixed Bangkok clay, Construction and Building Materials, $25,1521-1531$.

11)Horpibulsuk, S., Rachan, R., Suddeepong, A. and Chinkulkijniwat, A. (2011c): Strength development in cement admixed Bangkok clay: labolatory and field investigations, Soil and Foundations, 51(2), 239-251.

12)Kamon, M. and Bergado, D.T. (1992): Ground improvement technique, Proceeding of $9^{\text {th }}$ Asian Regional Conference on Soil Mechanics and Foundation Engineering, 526-546.

13) Kim, J.C. (2003): Dry-shrinkage mechanism of concrete and its prediction model, Proceeding of Korean Society of Pavement Engineers, 5-3, 32-41.

14) Lee, S.H. (1996): Characteristics of dry-shrinkage reducing additive, Proceeding of Korean Society of Pavement Engineers, 16, 1-4.

15) Natt, G.S. and Joshi, R.C. (1984): Properties of cement and lime-fly ash stabilized aggregate, Transportation Research Record 998, Washington, D.C., 32-40.

16) Nicholson, P. and Kasyap, V. (1993): Fly ash stabilization of tropical Hawaiian soils, Fly Ash for Soil Improvement'93 Sharp, D. K. ed., Geotechnical Special Publication (GSP), ASCE, 36, 15-29.

17) Nilo, C.C., Prietto, P.D.M., Carraro, J.A.H. and Heineck K.S. (2001): Bahaviour of compacted soil - fly ash - carbide lime mixtures, Journal of Geotechnical and Geoenvironmental Engineering, ASCE, 127(9), 774-782.

18) Osinubi, K.J., Amadi, A.A. and Eberemu, A.O. (2006): Shrinkage characteristics of compacted laterite soil - fly ash mixtures, NSE Technical Transaction, 41(1), 36-48.

19) Sherman (1974): Laboratory study of factors affecting the shrinkage characteristics of cement-treated base, www.dot.ca.gov/hq/research/researchreports/1974-1975/74-4 3.pdf FHWA.

20) Terashi, M., Tanaka, H., Mitsumoto, T., Niidome, Y. and Honma, S. (1980): Fundamental of lime and cement treated soils, Report of Port and Harbour Research Institute, 19(1), 33-62. 